\title{
Rethinking Transnationalism
}

\author{
ROGER WALDINGER \\ UCLA \\ waldinger@soc.ucla.edu
}

Recibido: 29.08 .2009

Aceptado: 24.02 .2010

For the contemporary student of international migration, the central intellectual problem is how to manage two competing methodological temptations of nationalism, on one hand, and transnationalism, on the other. Methodological nationalism is the more common approach, as in both scholarly and popular views, nation-states are thought to normally contain societies (as implied by the concept of «American - or Mexican or French - society»); from this perspective, the appearance of foreigners, with their foreign attachments, is seen as deviant, disrupting an otherwise integrated whole and one that is expected to disappear. Consequently, the scholars - like the nationals - stand with their back at the border, looking inwards, their focus fixed on the new arrivals. What they see is that the immigrants respond pragmatically to the opportunities that they encounter, searching for a better life and adapting a cultural toolkit that pays dividends in their new home. As the receiving environment is dynamic, its institutions open; the new arrivals respond in kind, crossing ethnic boundaries, heading away from others of their own kind and toward the mainstream, whatever that might be.

More recently, however, the alternative approach appears more enticing: as the movements of goods, services, ideas, and people (though the latter to a notably lesser extent) appear to be sweeping across boundaries, the epiphenomenon seems to involve the nation-state. From this standpoint, social relations and activities (if not societies) naturally extend across national boundaries. Looking across borders, the view is one of nation-states that have lost the capacity they once possessed to control the passage of people across frontiers; unable to keep out or extrude unwanted foreigners, they also find it hard to maintain the line between citizens and aliens, which, if not disappearing altogether, is increasingly blurred. Whereas ties to home and host country were previously seen as mutually exclusive, today's political and ideological environment appears more relaxed, as the shift from melting pot to multiculturalism legitimates the expression of and organization around home country loyalties. Thus, with stepped-up mi- 
gration has come the proliferation of activities linking the migrants to the places from which they come, whether of the routine sort, involving remittances, communication, and travel, or the more concerted activities of home country political engagement or immigrant philanthropy. Ours, it appears, is a transnational age, where there are few emigration states without diasporas that they are trying to mobilize; likewise, there are few emigrations where self-conscious diaspora social action is not to be found.

The transnational approach has considerable appeal: most importantly, it reminds us that to say international migration is to say cross-border connections. Whereas the mythology of the classic countries of immigration assumes that the newcomers are arriving in order to build a life in the new land in reality, it is often not the case: many migrants instead want to take advantage of the gap between rich and poorer places in order to accumulate resources designed to be used upon return back home. Some eventually act on these plans; others, whether wanting to or not, end up establishing roots in the country of arrival. Given the uncertain, transitional nature of the migration process, connections linking origin and destination places are ubiquitous. Large flows of remittances, migrant associations raising funds to help hometowns left behind, trains or airplanes filled with immigrants returning home for visits to kin and friends are features encountered wherever large numbers of international migrants are found throughout the contemporary world. These same phenomena transform the places from which the emigrants come, providing both the opportunities and the motivations to leave, which is why receiving states find that migrations, once begun, are so difficult to stop. For all these reasons, a transnational approach appropriately points us beyond the conventional perspective that defines the problem as one of «immigration», encouraging us instead to attend to the complex feedbacks linking points of origin and destination, interactions that are unquestionably affected by the specific realities on the ground, but reappear from one national context to another.

Though in theory, a transnational perspective can generate value-added, in practice, its scholarly implementation has left much to be desired. The problem, in part, is that connectivity between sending and receiving societies is at once cause and effect of international migration, which means that much of the literature does little more than prove the null hypothesis, discovering the crossborder activities of remittance sending or political involvement that migrations almost always produce. For the same reason, identifying the specifically «transnational» aspect of the phenomenon proves elusive. As indicated by the conceptual jungle that has quickly emerged - of which the terms «transnationalism», «transmigration», «transterritorialization», «transnational social field», «transnational social formation», «transnationalization», «transnational social life», «transnational livelihoods», and «transnational topographies» are but a sampler - the temptation to apply the prefix «trans» to one or another aspect of the migrant phenomenon has proven overwhelming, but without doing much to illuminate the matter at hand. In practice, much of the research has put the 
question back into the traditional «immigration» frame, focusing on the crossstate experiences of the migrants, neglecting the relevant interactions - whether between migrants and stay-at homes or between migrants and nationals - as well as the role of other actors, whether in home or host states, who condition migrants' ability to effectively engage across boundaries.

The literature's own preoccupation with the home country connection of the migrants largely accounts for the slippage back into the immigration frame. That tendency was evident early, when the anthropologists who first advanced the transnational perspective linked «transnationalism» to the experience of the so-called «transmigrants» - movers who opted neither to return home nor sever ties but rather engage with countries of origin and of destination (Glick Schiller et al, 1992). While parting company with the anthropologists on methodological grounds, Alejandro Portes and his collaborators advanced a similar view, contending that «it is the rise of a new class (emphasis added) of immigrants, economic entrepreneurs or political activists who conduct crossborder activities on a regular basis, that lies at the core of the [transnational] phenomenon (Guarnizo, Portes and Haller, 2003: 1213)». As it turns out, engaging in regular cross-border activities entails knowledge, money, and time, not to speak of legal rights, which is why only a small migrant elite enjoys the good fortune of living lives across borders. Most, instead, are captured by the societies in which they settle, a generalization which holds with even greater force for the migrants' offspring.

The emphasis on parsing one migrant type from another stands in tension with another oft-sounded theme, the insistence that the concept of a transnational social field provides the best way to conceptualize the connections linking migrants with stay-at-homes (Levitt and Glick Schiller, 2004). In this view, migrants gain simultaneous incorporation at both ends of the chain, in turn, providing a conduit for a flow of ideas, resources, and people that brings points of destination and settlement together. However, the prospects for simultaneous incorporation would be brighter were this the type of open world of dual citizenship and expanding migrant rights that the literature so clearly prefers. Unfortunately, the barriers to incorporation are all too visible, with receiving states showing at best modest interest in either expanding membership or making its benefits more widely accessible. Most importantly, of course, the migrants enjoy something to which too many of the stay-at-homes can only aspire, namely, residence in a rich country, almost all of which are convinced that they have let in too many newcomers and are intent on not repeating that mistake.

In the end, the problem is that the discovery of cross-border connections just begs the question. If international migration is a recurring phenomenon, it goes without saying that cross-state social action, whether uncoordinated or concerted, will also re-appear. Moreover, the analysis can't be confined to a so-called «transnational social field» linking movers and stay-behinds in distant and disparate location. That field, itself, is embedded in a broader field, made up of state and civil society actors here and there, who respond, in various ways to the chal- 
lenges and opportunities generated by the cross-state flows produced by migration. Consequently, the crucial analytical question is the one that the literature has yet to pose: namely, the relative strength of the relevant actors and processes - both cross-state and territorial - and their variability over space and time. Do the processes that cut across borders escape the control and of states and their peoples, and if so, for how long and to what extent? Or are cross-state connections mainly circumscribed by state actors and nationalizing forces, with migrant activity and identity increasingly confined to territorial boundaries, whether of receiving or sending states? Which, of the various forces involved in the triangular social field encompassing migrants here and there, are the most influential and where - whether on sending or receiving grounds - are those influences to be found? And how does the relative power of the interactants vary across relevant spheres, whether occurring in the cross-state dimension, involving the migrants and the stay-at-homes, or transpiring in the receiving state dimension, where the migrants encounter the nationals?

These are the questions that I have tried to explore in a series of papers written over the past few years, focusing on the regularity of international migration and its inevitable collision with the political processes by which nation-states attempt to keep themselves apart from the world (Waldinger, 2003, 2007a, 2007b, 2008; Waldinger and Fitzgerald, 2004). Since international migration is not just a social, but a political phenomenon, migrant cross-state social action, whether of routine or concerted kind is conditioned by the stateness of the receiving environment. Wealth remains contained within the boundaries of the rich states of the north, which both motivates migration and makes it a technique for taking advantage of the gap between rich and poorer places, whether by movers who accumulate resources for investment back home or instead send back remittances to support the stay-at-homes. While traversing the borders of the rich states may have become increasingly difficult, once inside, those borders have long proved protective, insulating migrants from the pressures of the home state, and providing them with political freedoms not previously available. The material and the political often combine: the wealth of the receiving country generates resources that give the migrants leverage back home; its more open, political system provides skills, allies, ideas, and experiences that add to the political weight that the migrants exercise back home and also change their priorities.

In the remainder of this paper, I would like to push the argument further, focusing on the interaction between migrants and stay-at homes, showing how the American experience at once facilitates and structures immigrants' involvements with the countries from which they come. To do so, I will examine a migration universal, namely the associations that bring together migrants displaced from a common hometown, drawing on the rapidly accumulating literature, as well as fieldwork conducted in Los Angeles and El Salvador and a variety of surveys that have collected data on immigrants' home country involvements. Sociologically interesting, these associations (to which I will refer as HTAs) highlight the convergence of academic preoccupations with the real 
world, as associational activity has triggered responses from international organizations and sending state actors, seeking to harvest political and economic rewards from these grassroots activities, undertaken by migrants in parallel, but uncoordinated form. Most importantly, they provide us with a strategic research site, allowing us to take apart the two very different aspects - namely, state and nation - that the transnational concept so unfortunately conflates. In coming together with their fellow hometowners, the immigrants show their attachment to a social collectivity defined in terms of common origin in some other place. But the long-distance identification of the migrant hometowners often takes the form of a «brotherhood of memory (Weisser, 1989)», involving social support and the exercise of nostalgia among migrants living in the place of destination, but no cross-state action that connects them to the stay-at-homes. Crucially, however, the upsurge of contemporary hometown oriented activity, while also nostalgia-driven, involves cross-state spillovers, in which resources generated «here» are used for ends «there». As I will now show, the potential for home country involvement at once derives from and is shaped by the bounded, receiving society resources that give the migrants new leverage not found before. Rather than linking immigrants and stay-at-homes in a single transnational community or social field, the cross-state activities undertaken by hometown associations yield not so much cross-state community, as cross-state conflict, reproducing inequalities between migrants and the stay-at-homes in ways that reflect the inequalities between receiving and sending places.

\section{HOMETOWN ASSOCIATIONS: THE POLITICS OF LONG- DISTANCE ATTACHMENTS}

Displaced from familiar ground and treated as strangers, migrants often discover a commonality in people originating from the same place. Finding comfort in the company of a familiar face, gaining pleasure from reminiscing about times gone by, or deriving satisfaction from the effort to make things better for the home and hometowners left behind, migrant hometowners repeatedly come together.

These connections and the organizations and activities that they spawn are a migration universal, to be found wherever and whenever long-distance migration occurs (Moya, 2005). Their ubiquity might explain why the most influential studies of the phenomenon called trans-nationalism, have instead focused on these cross-border, bi-local connections, linking particular places in sending and receiving states. Indeed, the most widely-cited, influential empirical studies almost always involve research of this kind. Salient examples include Roger Rouse's early work on the «migration circuit» linking a small community in Mexico's central plateau with Redwood City, located in California's Silicon Valley (1991; 1992); Peggy Levitt's 2001 book, The Transnational Villagers, a study of the ties connecting a small community in the Dominican Republic and 
its migrants living in Boston; Robert Smith's 2006 book on Mexican New Yorkers and the small town in Puebla from which they came and to which they, and some of their children, recurrently return; and Michael Smith and Matt Bakker's (2007) Citizenship across Borders, examining the political involvements of Mexican migrants in the states and communities from which they come..

As Smith notes, cross-border life of this sort is «not cosmopolitan, but local and parochial (2006: 63)». The analytic problem, however, is that the localistic connections linking hometowners here and there do not distinguish cross-border movement from long distance population movements of any other sort. In many respects, long-distance migrants are all one of a kind: as Michael Piore (1979) argued years ago, what matters is not the color of the identity card or the passport, but rather that migrants are social outsiders, evaluating conditions here, in light of the standards there. More importantly, long-distance migrants, whether international or internal, undergo similar experiences, namely those of displacement and strangeness, which is why they suddenly discover a commonality in people originating from the same place. Indeed, the anthropological literature on third world migrations, from which the scholarly transnationalists drew their inspiration (e.g. Mayer, 1962), is replete with such examples, to which could be added similar, though less commonly noted cases from the historical literature on intra-European migration, migration in China, or for that matter, rural-to-urban migration in the United States.

To say that trans-state bi-localism strongly resembles intra-state bi-localism is not to say that they are the same. Within the national container, developed and developing states have often turned peasants into nationals, while intra-state, regional differences have also declined. Both changes have reduced the displacing impact of internal migration, attenuating the impetus to seek solace in the company of those hometowners who have similarly converged on the big city. By contrast, the move across the national border generally remains a more deeply foreign experience, though less so in developing societies, where strangeness is still enough to bring contemporary migrants together with their fellow hometowners, as among Kurds in today's Istanbul (Celik, 2005). Likewise, timespace compression has weakened intra-border localism, as internal migrants seeking to indulge hometown longings need no longer turn to one another, but can instead return for a visit, at relatively low costs (Fitzgerald, 2008). Since distance, by contrast, is more likely to impede international migrants, who also need the right documents in order to return home, the bond to fellow hometowners in the place of destination is more likely to remain strong. Again, the difference is one of degree, not of kind, as illuminated by a recent article on the use of the internet in the diaspora, the particular diaspora in question being that of contemporary Canadian migrants from the province of Newfoundland, displaced to the distant, but oil-rich province of Alberta (Hiller and Franz, 2004).

The key point is that sociological factors explain both why long-distance migration activates hometown ties and why border-crossing usually generates hometown associations with greater intensity than the movements that take 
place within state boundaries. However, ties of this sort need not generate any further cross-border activity. Historically, hometown associations were mainly a tool by which the migrants solved their own problems, whether having to do with needs for sociability or the practical matters of pooling savings to provide burial insurance or medical funds, though crises at home episodically motivated the migrants to help out the communities they left behind (Soyer, 1997). In the contemporary United States, the search for familiar faces continues to draw hometowners together; however, the locus of the activists' instrumental objectives has changed, abandoning the goal of solving problems at the point of reception, and focusing instead on sending places.

That shift has also activated a new set of players, transforming a topic of academic study into a matter of interest to policy makers and political officials. The stimulus, in part, comes from the rapidly emerging awareness of immigrant remittances and their impact on developing countries. Remittances received by developing countries are large (the second largest source of development finance after direct foreign investment); rising (up by almost 100 percent between 1999 and 2004); stable (with less volatility than other sources, such as capital market flows or development assistance); and free, requiring neither interest nor repayment of capital (Ratha, 2005).

Seen as an effective means of reducing poverty and a form of self-help, remittances have become the «new development mantra», as argued by the political scientist, Devesh Kapur (2005). The linkage between remittances and development strikes the right cognitive chord consistent with the preferences of a communitarian, third-way approach to development (Kapur and McHale, 2005); it also reflects a widely shared conviction that connections to the expatriates lost due to migration can be turned to sending countries' gain. In the view of contributors to a recent World Bank study, migrants can serve as bridges, «providing access to market, sources of investment, and expertise» while also helping to «shape public debate, articulate reform plans and help implement reforms and new projects» (Kuznetsov and Sabel, 2006:3). Though transforming brain drain into brain gain is the most alluring way of activating the so-called diaspora, there is considerable interest in how the more numerous low-skilled migrants might also generate positive spillovers via their hometown associations. While the very great bulk of migrant remittances result from the individual preferences of immigrants acting in parallel, but uncoordinated fashion, the size of the flow is such that decisions to channel even a small proportion of the funds in the form of «collective remittances» could yield significant impact. Moreover, migrant philanthropy, as it has come to be called, appears to be a grassroots phenomenon, an additional virtue in the eyes of development policymakers, convinced that economic performance and broader participation go hand in glove (Burgess, 2005). From the standpoint of development agencies, the prospect that immigrant associational activity in the developed world could leverage capital and participation for stay-at-homes in the developing world seems worth the gamble, as evidenced by a rapidly expanding portfolio of research and program development 
grants.

Sending state officials are no less interested in «collective remittances», though they are affected by a somewhat different mix of motivations. To begin with, the migrants are political actors, deploying resources that make it impossible for them to be ignored. Unlike taxpayers, moreover, the migrants are willing to reach into their own pockets and provide money for free, reason for cash-strapped governments in developing societies to find ways of keeping the flow moving. Just how best to engage in «remittance capture» (Gamlen, 2008) is a question with which sending states around the world are struggling, discarding old policies for new policies in the hope that some innovation will produce better results.

Thus far, no one has yet found a tool that would steer family remittances in ways that might directly trigger development; hence, interest has focused on how home state governments might stimulate migrant giving; Mexico's «Tres por uno» program, in which each HTA dollar raised for investment back home is matched by a dollar from the Mexican federal, state, and municipal government is perhaps the best known such effort. Success in capturing HTA collective investments can also yield political gains for the political leaders who bring these benefits home, as noted by the authors of a recent UN Development Program report on Mexican Migration who write that state «governors and political parties frequently try to influence the selection of projects and financing and to co-opt the migrant organizations (Programa De Las Naciones Unidas Para El Desarrollo, 2007:95)». Last, precisely because they are the most engaged with the homeland, the hometown activists can be a link by which home country states can exercise influence with those emigrants whose ties are otherwise attenuating. Indeed, the director of Mexico's Institute for Mexicans Abroad, a government agency, has seen engagement with hometown associations as a way to use «the natural mechanisms of organization among countrymen to strengthen their identity as members of the Mexican diaspora (Gonzalez Gutierrez, 1999: 559)»

Whether hometown associations can effect change in the communities from which the immigrants come, and if so, of what type, depends largely on the quality and content of the linkages connecting the migrants to one another, to the friends, families, and neighbors left at home, as well as to the other actors that have now engaged in the game. Scholarly views range the spectrum, with little consensus as to consequences, whether positive or negative, or the features that limit or propel successful associational activity. In establishing the balance sheet, one can begin by noting that associational activity is on the rise - with the number of Mexican HTAs registered with the Mexican government increasing from roughly 250 to over 600 between 1995 and 2003 and notable levels of HTA growth among immigrants from El Salvador and a range of countries in the circum-Caribbean. On the other hand, HTA involvement, unlike remittance-sending, is a distinctively minoritarian phenomenon. The Pew Hispanic Center's 2006 Survey of Latinos, for example, provided ample evidence of lively home country connections, with half of the roughly 2,000 foreign-born respondents 
sending remittances to relatives in their country of origin, forty percent calling friends and relatives at least once a week, and two-thirds reporting at least one trip home, after migration to the United States. By contrast, only nine percent reported belonging to an immigrant civic, sport, or hometown association, with higher levels among Dominicans and Colombians, and lower levels among Mexicans, the overwhelmingly dominant group (Waldinger, 2007).

Not surprisingly, that minority engaged in associational matters represents an immigrant elite. As described in a recent review article appearing in a book on Mexican hometown association published by the University Guadalajara Press:

In the great majority of cases, it is a matter of migrants of the first generation, well established in the United States (a decade or more after having migrated), who have already achieved a certain socio economic level: many of them are owners of small businesses (insurance, real estate, Mexican restaurants); some are professionals (lawyers, social workers, doctors) or government employees. At the same time, the majority of leaders and members are men... (Escala-Rabadan, 2004: 435).

The surveys tell a similar story. Analysis of the Pew Center Survey shows, not surprisingly, that higher incomes, more education, and greater time spent in the United States all increase the probability of associational membership. Likewise, Alejandro Portes' summary of the findings of the Comparative Entrepreneurship and Immigration Project tells us that cross-border activity is:

...mainly the pursuit of solid, family men - educated, well-connected and firmly established in the host country. They, rather than the recently arrived and the downwardly mobile, organize cross-border enterprises; support political parties and civic committees in their countries; and lead the cultural festivities, sports and religious events linking each migrant diaspora with its respective nation (Portes, 2003).

Not only is hostland participation highly selective, biasing HTAs activities in a direction consistent with the interests of those who participate, the organizations are structured in ways that promote capture by those who are most heavily engaged. In general, the associations have no paid staff, depending instead on the willingness and availability of volunteers to donate time, energy, and cash in the interest of some public good. It is not even clear that they have members either, a fact reflecting both the low level of organizational formality and the episodic nature of the HTAs' engagement with the larger, relevant collectivity. As noted by the Mexican study cited above, «membership» is rarely a clearly defined category, possibly pertaining to families or to individuals (Escala-Rabadan, 2004).

If the activists comprise a selective group, agreement on goals and means often eludes the minority that opts for participation. The historical literature - perhaps because time facilitates distance from the subject matter - underscores the potential for conflict, an issue that contemporary scholars seem to underplay. 
As bi-localism competes with other loyalties that emphasize politics or ideology over affective ties, hometown associations need to find a way to unite right and left, believers and secularists, proletarians and entrepreneurs - which is why their anti-political bias has often been so strong. Indeed, keeping principled differences at bay requires continuous work, as indicated by the three-point «philosophy» of an association of Salvadoran hometown associations - «no politics, no religion, no profit».

In addition to principled differences, self-interest yields ample reasons to fight. As the HTA context often provides opportunities for persons of very modest circumstances to gain recognition that they would rarely otherwise obtain, status-seeking is often the source friction and faction. The tendency toward secession, amply noted in the historical literature, was easy to detect in my fieldwork among Salvadorans. Since the impediments to starting up a rival group are low, and populations are often large enough to support more than one association from the same hometown, activists unhappy with their leaders have plenty of incentives to set up a rival group.

One alternative, of course, is rule by a self-perpetuating elite, noted in a recent UN Development Program report on immigration's impact on El Salvador which recounts that «many groups suffer from little leadership rotation, including some that had the same president for more than a decade (Programa De Las Naciones Unidas Para El Desarrollo 2005, 265)». Indeed, this is the story recounted in Robert Smith's recent book, Mexican New York, the most detailed, most ethnographically rich account of immigrant bi-localism that the literature has produced. As he explains, the HTA of Ticuanenses living in New York is a player, perhaps the dominant force in the town from which the migrants began to leave decades before. Smith emphasizes the Committee's role in displacing the local cacique from power, and fostering democracy in Ticuani. What gets less attention is the fact that the Committee itself appears guilty of caciquismo. As Smith explains, the committee «has been run by the same men for thirty years» - indeed with a single individual holding the presidency throughout that entire span of time (62), «whereas the municipio's leadership changes every three years..». (57). While at least some of the migrant Ticuanenses dissent from the Committee's priorities, there is little that they can do to make their opinions matter. Indeed, the unusually tight-knit nature of this population means that influence typically flows the other way, with the committee able to «create a socially coercive context» (64) that gets the migrants Ticuanenses to take cash out of their pockets in response to the committee's appeals.

But not only do the HTA activists comprise a selective population with at best limited responsiveness to the broader migrant masses that they claim to represent, the interaction with the stay-at-homes tends to reproduce the very inequalities between receiving and sending places that motivated the migration in the first place. Although the literature emphasizes the boundary-spanning aspects of immigrant «transnationalism», its preconditions are in fact the boundaries that separate receiving and sending communities. Movement to a new place gives the 
migrants freedom not possessed before; as emphasized above, residence in a rich country means that even people of modest means have access to resources that can make a difference back home. For the same reason, therefore, they can exercise leverage in their dealings with home community interactants, a factor making for imbalance in the relationship between the two sets of hometowners and increasing the likelihood that the migrants will have access to home society influentials, not fully shared by the hometown rank and file.

The research on Salvadoran associations, for example, shows that the initiatives begin in the U.S. Similarly, the fundamental choices are for the migrants, not the stay-at-homes, to decide: which goals are to be met, how help is to be delivered; to whom assistance should be provided. Likewise, the question of how, if at all, to involve the stay-at-homes - whether as partners, advisors, or simply as the more or less passive recipients of help - is a matter for the migrants to decide. The migrants' goals are affected by any number of factors, starting with their desire to do good for their hometown and hometowners. But HTA views of how best to do good are largely ad hoc. Their preferences frequently lead to visible physical investments, such as the construction of recreational facilities or the renovation of a church. Both may be commendable, but neither fulfills the hopes vested in HTA activities - namely, that they will relieve migration pressures; too often, they end up providing «mausoleums of nostalgia», shoring up physical structures in communities that can no longer hold on to their own people.

Moreover, HTA goals are also often not fully realistic and therefore not fully consistent with the preferences of the stay-at-homes or local officials. In particular, the HTAs tend to underestimate long-term costs of maintaining investments in physical goods, as noted in a recent World Bank study which found that many of the projects financed by Mexican migrants suffer from lack of sustainability (Torres and Kuznetsov, 2006). Symbolizing that problem are the many ambulances donated by migrants to their home communities, which all too often end up sitting immobilized because there are no funds for maintenance, or for that matter, the skilled personnel needed for operation.

Moreover, while the HTAers want to do good, it is not clear that they only want to do good: physical investments are tangible products, reminding the stay-at-home public of the good that the HTAers have done. Nor is HTA goalsetting immune to the influence of naked self-interest, which can yield hometown investments that suit the migrants, but not necessarily the stay-at-homes, as suggested by the following case from a high emigration zone in El Salvador:

Case study: The hometown in El Salvador is a classic migrant sending community, located in one of the poorest of the country's regions, but now filled with large houses. The caserio is the Beverly Hills of the municipio, displaying modernization without development: nice and well-constructed houses, paved roads, electricity, landlines and cell phones for almost every inhabitant of the caserio. However there is no drinking water nor a sewage 
system. They still get the water from a water well. For the local residents, furnishing the funds that could provide drinkable water has been the most important goal sought from the hometowners living in the United States. The HTA, however, has had different priorities...While it funded construction of a well, the work was done in the property of a relative of the association's president. Sometime afterwards, the water pressure dropped, disrupting the flow to the rest of the village. The well, however, is sufficient to service the needs of the family of the association's president....

While those who hold the resources do not always engage in equally selfseeking behavior, the literature provides ample evidence of imbalance in the relationship between migrant hometown activists and stay-at-homes. Peggy Levitt's The Transnational Villagers (2001), a study of the connections between a group of Dominicans living in Boston and their hometown of Miraflores in the Dominican Republic, includes a chapter focusing on a development committee started by the migrants. Here, Levitt depicts the committee as a grassroots effort yielding positive effects: investment in hometown public goods; the fostering of social capital, in part by stimulating broader participation, in both home and host-towns; and increased hometown government accountability, as migrants' dollars and pressure gave stay-at-homes greater leverage over state officials. The details of the account, however, point in a different direction. Notwithstanding the many informal exchanges that had regularly passed through the migrant circuit, migrants were at first skeptical of organized efforts to assist development in Miraflores, in part because previous such ventures had taken advantage of migrant contributors seeking to do good (187). As of the time of writing, the development committee had developed procedures that were unusually standardized for organizations of this type - in part, because an individual involved in an earlier fund-raising activity had been able to take private control of property bought with collective funds (189-90). In the end, as Levitt notes, the inherent inequalities between the Mirafloreños in Boston and those still living in the Dominican Republic, skewed the development committee's activities and objectives, with decision-making gravitating to the Bostonians, whose priorities increasingly diverged with the Mirafloreños still living in Miraflores.

Quite a similar story emerges from Robert Smith's account of the balance of power between the Mexican New Yorkers and the stay-behinds. The local caciques, explains Smith, «face demands from well-funded migrants» (79), who can take advantage of changes in the Mexican political system to make their opinions heard and have their dollars «neutralize...the caciques' local advantage of wealth» (83). Migrant donations, for example, helped a challenger mobilize a caravan in ranchos that had previously supported the cacique, contributing, in 1999 , to the challenger's electoral success. However, the hometown committee in New York, split between supporters of the cacique and supporters of the challenger, remained neutral in the election; afterward it refused to support the new mayor's projects, with the result, as Smith explains of «denying him access 
to Ticuanense dollars in NY and making it impossible to do large-scale projects» (84). According to Smith, the new mayor, who saw the committee president as «the New York counterpart to the Tiquani cacique» (85), interpreted the committee's action as punishment for ending their arrangement with the long-reigning cacique. And as Smith's book shows, municipal politics is not an exception, but rather the rule, as differences in the resources linked to place of residence consistently divide and oppose the Ticuanenses living in New York from their counterparts who have yet to leave home.

\section{CONCLUSION}

Positioning themselves against the view that immigrants were the uprooted, the scholars who first introduced the transnational perspective to migration studies contended that an increasing number of movers, opting neither to return home nor sever ties, represented a distinctive social type. Now labeled the «transmigrants», these movers «develop and maintain multiple relations - familial, economic, social, organizational, religious, and political that span borders (Glick-Schiller et al, 1992:1)».

The hometown association, as I have shown in this paper, is the quintessential form of immigrant long-distance attachment, to which the scholarly transnationalists have rightfully drawn our attachment: immigrants' predilection for seeking the company of their fellow hometowners is a phenomenon that every student of immigration, past or present, will recognize. In extending their scope from sociability in the new land to development in the old country, the HTAs of the contemporary period further demonstrate, just as the scholarly transnationalists insist, that the migrants are not all uprooted. Instead, flows of various sorts continue to move across borders and social relations in the new home remain structured by connections brought from the old. For these reasons, the study of hometown associations also highlights the two quite separate dimensions that the «transnational» concept unfortunately conflates, namely attachment to a social collectivity identified with the place left behind, which the migrants can pursue through mutual aid or nostalgic get-togethers, and cross-state social action, in which the migrants generate flows that converge back on the place from which they came.

Focusing on an explicitly cross-border expression of immigrants' home country ties, this study of HTA involvement with migrants' home towns provides little support for the view that sending and receiving communities are encompassed by transnational social fields in which persons participate and belong to a common social world, regardless of physical location. While one can agree with those scholars who have emphasized the «power of status» deployed by the so-called «transmigrants» when intervening in «transnational social fields» (e.g., Goldring, 1998), it does appear that they have not carried the observation to its logical conclusion: namely, that the real estate agent's maxim of «location, location, location» is what proves decisive. 
With action shifting to the trans-border axis, in turn triggering responses from other actors, the migrants' ability to exercise leverage back home derives from the bounded, territorial resources that they access by virtue of cross-border movement from poor to rich states. To a large extent, that potential derives from the same conditions that motivated the migration in the first place: by collecting funds in countries where wages are high in order to support changes in countries where costs are low, small contributions from low-wage migrant workers are enough to give hometown activists the resources they need to make a difference back home. Moreover, even among the most disadvantaged migrants, not all the migrants stay at the bottom; many instead experience upward movement, with some of the more successful migrants putting their means, as well as their contacts, at the disposal of the trans-state activists.

Asking just how the hometowners «here» and «there» can actually collaborate, and which of the hometowners on either side of the divide participate in the process, moves the obstacles to cross-state cooperation into clearer relief. Not everyone can go from «here» to «there» and back with equal ease: the stay-athomes are largely precluded from on site intervention with the HTAers living in the new land. Among the migrants, only a selective minority participates in associational matters. As travel back to the hometown requires legal and economic resources that all too many migrants don't yet possess, the crucial interlocutors comprise a still smaller group. Indeed, among respondents surveyed randomly by the Comparative Entrepreneurship and Immigration Project directed by Alejandro Portes, 90 percent never returned to their hometowns to participate in fiestas or celebrations and only 2 percent did so regularly. While individual communication with close relatives may be easier in the era of the cell phone and internet then it was in the day of the trans-Atlantic letter, distance and geographical separation still matter, producing high transaction costs that impede effective contact between migrant activists and home town communities, as a World Bank study recently concluded (Torres and Kuznetsov, 2006).

That the migrants present themselves as hometowners, moreover, does not mean that they are actually one and the same. As many scholars have noted, the impetus for hometown-oriented activity frequently derives from rejection in the new land. However, the satisfaction sought from intervention in the community left behind often bespeaks unequal, not collaborative, relationships with the stay-at-homes, with the migrants committed to goals that are tenuously related to the priorities of the communities from which they come.

In the end, this effort to focus on the specifically trans-border dimension of immigrants' homeland affections does show that trans-state connections are an inherent aspect of international migration, albeit in varied and unpredictable ways. As international migration escapes states' efforts to border their populations, it generates ideational, cultural, economic, and political spillovers that in turn yield significant effects, on both receiving and sending ends. The content and form of those spillovers, however, are not determined in advance. More importantly, those spillovers are both shaped and constrained by the bounded nature 
of the environment into which the migrants have come. While communities of all kinds are internally differentiated, characterized by inequalities of myriad sorts, the cleavages in the cross-state communities studied here are distinctive in that they coincide exactly with the borders of national states. It is by moving across borders into the territory of a rich state that the migrants have gained opportunities to affect change back home, doing so in ways that reflect, and largely reinforce, the inequalities between sending and receiving societies.

\section{BIBLIOGRAPHY}

BURGESS, K. (2005): «Migrant Philanthropy And Local Governance» in Barbara Merz, New Patterns for Mexico: Observations on Remittances, Philanthropic Giving, and Equitable Development, Cambridge, Harvard University Press.

Celik, A. B. (2005): «'I miss my village' Forced Kurdish Migrants in Istanbul and their representation in associations», New Perspectives on Turkey, No. 32, pp. 137163.

Escala-RABADAN, L. (2004): «Migracion y formas organizatives en los Estados Unidos: los clubes y federaciones de migrantes mexicanos en California» in Lanly, Guillaume and M. Basilia Valenzuela V. (eds), Clubes De Migrantes, Oriundos Mexicanos En Los Estados Unidos: La Political Transnacional De La Nueva Sociedad Civil Migrante, Guadalajara, Universidad de Guadalajara, pp. 425-454.

FitzGERALD, D. (2008): «Colonies of the Little Motherland: Membership, Space, and Time in Mexican Migrant Hometown Associations» Comparative Studies in Society and History 50(1).

Gamlen, A. (2008): «The emigration state and the modern geographical imagination» Political Geography, V 27, pp. 840-856.

GonZaLez GutierREZ, C. (Sep. 1999): «Fostering Identities: Mexico’s Relations with Its Diaspora» The Journal of American History, Vol. 86, No. 2, Rethinking History and the Nation-State: Mexico and the United States as a Case Study, A Special Issue, pp. 545-567.

GoldRING, L. (1998): «The Power of Status in Transnational Social Fields» in Michael Peter Smith and Luis Eduardo Guarnizo, eds., Transnationalism from Below. New Brunswick, N.J.: Transaction Publishers.

Guarnizo, L., Portes, A. AND Haller, W. J. (2003): «Assimilation and Transnationalism: Determinants of Transnational Political Action among Contemporary Migrants» American Journal of Sociology, Vol. 108, No. 6, pp. 1211-1248.

Hiller, H. and Tara Franz. (2004): «New ties, old ties and lost ties: the use of the internet in diaspora», New Media and Society. V, 6 (6), pp. 731-752.

KAPUR, D. (2005): «Remittances: the New Development Mantra?» in Remittances: Development Impact and Future Prospects, edited by Samual Munzele Maimbo and Dilip Ratha, Washington, DC, The World Bank, pp. 331-361.

KaPUR, D. AND McHale, K. (2005): Give Us Your Best and Brightest: The Global Hunt for Talent and its Impact on the Developing World, Washington, Center for Global Development.

KuZnETSOv, Y. AND SABel, C. (2006): «Internaitonal Migration of Talent, Diaspora Networks, and Development: Overview of Main Issues» in Yevgeny Kuznetsov, Dias- 
pora Networks and the International Migration of Skills, Washington, DC, World Bank, pp. 3-20.

LeVITT, P. (2001): The Transnational Villagers, Berkeley, University of California Press.

LevitT, P. AND Glick SchILleR, N. (2004): «Transnational Perspectives on Migration: Conceptualizing Simultaneity«, International Migration Review, vol. 38 no.3, pp. 1002-1039.

MAYer, P. (1962): «Migrancy and the Study of African Towns», American Anthropologist, 64, 3, pp. 576-592.

MoYA, J.C. (2005): «Immigrants and associations: a global and historical perspective», Journal of Ethnic and Migration Studies, 31,5 .

Piore, M. (1979): Birds of Passage. Cambridge, Cambridge University Press.

PORTES, A. (2003): «Conclusion: theoretical convergencies and empirical evidence in the study of immigrant transnationalism», International Migration Review 37,3 .

Programa De Las Naciones Unidas Para El Desarrollo (2005): Informe sobre el desarrollo humano en El Salvador: Una Mirada al Nuevo Nosotros. El Impacto de las Migraciones, San Salvador, El Salvador, PNUD.

Programa De Las Naciones Unidas Para El Desarrollo (2007): Informe sobre desarrollo humano: México 2006-2007, Mexico City, PNUD.

Rouse, R. (1992): «Making Sense Of Settlement - Class Transformation, Cultural Struggle, And Transnationalism Among Mexican Migrants In The United-States» in Nina Glick Schiller, Linda Basch and Cristina Blanc-Szanton, Towards a Transnational Perspective on Migration: Race, Class, Ethnicity, and Nationalism Reconsidered, New York, N.Y., New York Academy of Sciences, pp. 25-52.

SMITH, M.P. AND BAKKER, M. (2008): Citizenship across borders : the political transnationalism of el migrante, Ithaca, Cornell University Press.

Smith, R.C. (2006): Mexican New York, Berkeley, University of California Press .

SOYER, D. (1997): Jewish Immigrant Associations and American Identity in New York, 1880-1939, Daniel Soyer. Cambridge, Mass, Harvard University Press.

Torres, F. AND KuZnetsov, Y. (2006): «Mexico: Leveraging Migrants' Capital to Develop Hometown Communities» in Yevgeny Kuznetsov, Diaspora Networks and the International Migration of Skills, Washington, DC, World Bank, pp. 99-128.

WALDINGER, R. (2003): «Foreigners Transformed: International Migration and the Making of a Divided People», Diaspora, 12, 2, pp. 247-272.

Waldinger, R. (2007a): «The Bounded Community: Turning Foreigners into Americans in $21^{\text {st }}$ Century Los Angeles» Ethnic and Racial Studies, V 30, 7, pp. 341-374.

- (2007b): «Transforming Foreigners into Americans» in Mary Waters and Reed Ueda, eds., The New Americans, Cambridge, Harvard University Press, pp. 137-148.

- (2007c): «Between Here and There: How Attached are Latino Immigrants to their Native Country» Report, Pew Hispanic Center, October 25.

- (2008): «Immigrant 'Transnationalism' and the Presence of the Past» in Elliott Barkan, et. al., eds. Borders, Boundaries, And Bonds: America And Its Immigrants In Eras Of Globalization, New York, New York University Press, pp. 267-285.

- AND FitzGERALD, D. (2004): «Transnationalism in Question» American Journal of Sociology, V 109, 5, pp.1177-1195.

- (1989): A brotherhood of memory : Jewish landsmanshaftn in the New World, Ithaca, Cornell University Press. 


\title{
RESUMEN
}

Al centrarnos en la interacción entre las personas que migran y las que permanecen, este artículo muestra cómo la experiencia en el país anfitrión facilita y estructura rápidamente las relaciones de los inmigrantes con sus países de origen. La vía utilizada es un estudio de la migración global: las asociaciones que unen inmigrantes desplazados desde su mismo lugar natal. Estas asociaciones proporcionan un lugar estratégico para la investigación, permitiéndonos separar dos aspectos muy distintos -a saber, estado y nación- que el concepto transnacional engloba. Al reunirse con compañeros del mismo origen natal, los inmigrantes muestran su apego hacia una colectividad social definida en términos del origen común en alguna otra parte. Sin embargo, ese aumento de la actividad orientada al lugar de origen implica también excedentes entre los estados, de forma que los recursos generados «aquí» se usan como fines «allí». Como muestra este artículo, el potencial para las relaciones con el país de origen se deriva y se configura inmediatamente por lo fronterizo, por la palanca que los recursos de la sociedad receptora suponen para los migrantes y que antes no podían encontrar. Más que ligar a los que migran y a los que no lo hacen en una sola comunidad transnacional o campo social, las actividades trans-estatales emprendidas por las asociaciones del origen natal dan lugar, no tanto a una comunidad entre los estados, sino a un conflicto trans-estatal, reproduciendo las desigualdades entre los migrantes y los que permanecen en formas que reflejan las desigualdades entre los lugares receptores y de origen.

\section{PALABRAS CLAVE}

Transnacionalismo, asociaciones de inmigrantes, asociaciones de origen.

\begin{abstract}
Focusing on the interaction between migrants and stay-at homes, this paper shows how the host country experience at once facilitates and structures immigrants' involvements with the countries from which they come. The vehicle is a study of a migration universal: the associations that bring together migrants displaced from a common hometown. These associations provide a strategic research site, allowing us to take apart the two very different aspects - namely, state and nation - that the transnational concept conflates. In coming together with their fellow hometowners, the immigrants show their attachment to a social collectivity defined in terms of common origin in some other place. However, the upsurge of contemporary hometown oriented activity also involves crossstate spillovers, in which resources generated «here» are used for ends «there». As this paper shows the potential for home country involvement at once derives
\end{abstract}


from and is shaped by the bounded, receiving society resources that give the migrants new leverage not found before. Rather than linking immigrants and stayat-homes in a single transnational community or social field, the cross-state activities undertaken by hometown associations yield not so much cross-state community, as cross-state conflict, reproducing inequalities between migrants and the stay-at-homes in ways that reflect the inequalities between receiving and sending places.

\section{KEY WORDS}

Transnationalism, immigrant associations, hometown associations. 